ISSN 2442-3041

Math Didactic: Jurnal Pendidikan Matematika

Vol. 1, No.1, Januari - April 2015

(C) STKIP PGRI Banjarmasin

\title{
KEEFEKTIFAN PEMBELAJARAN KOOPERATIF TIPE STAD DAN STAD “PLUS" PADA MATERI TRIGONOMETRI ${ }^{8}$
}

\author{
Rakhmawati \\ SMA Negeri 1 Amuntai \\ E-mail: rakhmawati.mat.ks@gmail.com
}

\begin{abstract}
Abstrak: Penelitian ini bertujuan untuk: 1) mendeskripsikan keefektifan pembelajaran kooperatif tipe $S T A D$ dan tipe $S T A D$ "plus", serta pembelajaran konvensional; 2) membandingkan keefektifan antara pembelajaran kooperatif (tipe STAD dan tipe $S T A D$ "plus") dan pembelajaran konvensional; dan 3) membandingkan keefektifan antara pembelajaran kooperatif tipe STAD dan tipe STAD "plus", dalam pembelajaran matematika materi trigonometri ditinjau dari prestasi, minat, dan motivasi belajar siswa SMA. Penelitian ini merupakan penelitian eksperimen semu dengan menggunakan dua kelompok eksperimen dan satu kelompok kontrol. Populasi penelitian mencakup seluruh siswa kelas X SMA Negeri 1 Depok, Sleman. Sampel penelitian terdiri dari tiga kelas yang dipilih secara acak. Instrumen penelitian adalah instrumen tes prestasi, angket minat dan motivasi belajar. Analisis data meliputi: 1) uji tone sample; 2) analisis multivariat dengan Helmert Contrast; 3) uji lanjut dengan Tukey. Hasil penelitian menunjukkan bahwa: 1) pembelajaran kooperatif tipe $S T A D$ dan tipe $S T A D$ "plus" efektif ditinjau dari minat dan motivasi tetapi tidak efektif ditinjau dari prestasi, sedangkan pembelajaran konvensional tidak efektif ditinjau dari ketiga variabel dependen; 2) pembelajaran kooperatif tipe $S T A D$ dan tipe $S T A D$ "plus" lebih efektif daripada pembelajaran konvensional ditinjau dari minat dan motivasi belajar matematika siswa; 3 ) tidak terdapat perbedaan keefektifan antara pembelajaran kooperatif tipe STAD dan tipe STAD “plus" ditinjau dari prestasi, minat, dan motivasi belajar matematika siswa.
\end{abstract}

Kata kunci: pembelajaran kooperatif, STAD, STAD “plus”, prestasi, minat, dan motivasi belajar

Minat dan motivasi belajar siswa merupakan dua hal yang mempengaruhi kualitas pencapaian belajar siswa. Schunk, Pintrich, \& Meece (2010: 211) menyatakan bahwa orang akan belajar atau bekerja dengan baik apabila mereka berminat dan tidak akan belajar atau bekerja dengan baik apabila mereka tidak berminat. Seorang siswa yang menaruh minat besar terhadap matematika akan memusatkan perhatiannya lebih banyak daripada siswa lainnya, karena pemusatan perhatian yang intensif terhadap materi itulah yang memungkinkan siswa untuk belajar lebih giat, dan akhirnya mendapat prestasi yang diinginkan (Muhibbin Syah, 2010:152). Motivasi adalah sesuatu yang memberi energi, mengarahkan, dan mempertahankan perilaku (Ormrod, 2003: 368). Secara umum, menurut

\footnotetext{
${ }^{8}$ Disampaikan pada Seminar Nasional Pendidikan Matematika STKIP PGRI Banjarmasin, 28 Januari 2015
} 
Elliot, et al. (2000: 332) orang yang memiliki motivasi lebih tinggi akan meraih hasil yang lebih baik, bahkan Orlich, et al. (2007: 18) menyatakan bahwa guru dapat mengajar hanya apabila pebelajar memiliki motivasi untuk belajar.

Upaya meningkatkan prestasi, minat, dan motivasi siswa dalam proses belajar mengajar, salah satunya yang bisa dilakukan oleh guru adalah penerapan suatu model atau metode pembelajaran dan pemvariasian dalam media pembelajaran yang digunakan, sebagaimana diungkapkan oleh Kozma (1994: 11) bahwa "media and methods together influence learning. ... While learning, students interact with both media and methods", yang artinya bahwa media dan metode bersamasama mempengaruhi pembelajaran. Selama pembelajaran, siswa berinteraksi dengan keduanya, media dan metode. Namun permasalahannya, suatu model atau metode pembelajaran dan suatu media pembelajaran yang ada tidak menjamin akan berpengaruh dan efektif untuk diterapkan pada setiap materi. Penelitian ini menerapkan model pembelajaran kooperatif tipe STAD yang tanpa penggunaan media Power Point dan tipe STAD "plus" yang ditambah dengan penggunaan media Power Point (dengan sisipan gambar atau ilustrasi gambar tentang kegunaan atau penerapan trigonometri dalam kehidupan) pada materi trigonometri kelas $\mathrm{X}$ SMAN 1 Depok, Sleman, Yogyakarta tahun pelajaran 2011/2012.

Prestasi, minat, dan motivasi belajar matematika siswa kelas X SMAN 1 Depok Yogyakarta sebelum diberikan perlakuan dengan menerapkan model pembelajaran kooperatif tipe STAD dan STAD "plus" belum seperti yang diharapkan. Selain itu, keaktifan siswa juga dapat dikatakan belum maksimal. Metode pembelajaran sebelumnya yang biasa diterapkan guru menjadikan guru lebih mendominasi pelaksanaan pembelajaran dan media pembelajaran yang digunakan hanya berupa buku teks dan papan tulis. Akibatnya, siswa menjadi bosan, kurang berminat, dan kurang termotivasi dalam mengikuti proses pembelajaran, sehingga prestasi belajar matematika siswa juga belum sesuai dengan harapan.

Tujuan dalam penelitian ini adalah mendeskripsikan keefektifan model pembelajaran kooperatif tipe STAD, STAD "plus" dan juga pembelajaran yang biasa dilakukan sebelumnya yaitu pembelajaran konvensional, ditinjau dari prestasi, minat, dan motivasi belajar matematika siswa. Selanjutnya menyelidiki model pembelajaran yang lebih efektif antara model pembelajaran kooperatif dengan pembelajaran konvensional, serta antara kedua model pembelajaran kooperatif yaitu tipe $S T A D$ dan $S T A D$ "plus" ditinjau dari prestasi, minat, dan motivasi belajar matematika siswa.

\section{Metode}

Jenis penelitian ini adalah penelitian eksperimen semu (quasi- experimental). Rancangan eksperimen yang digunakan adalah nonequivalent groups pretest - posttest control group design (McMillan \& Schumacher, 2010: 278). Penelitian ini dilaksanakan di SMA Negeri 1 Depok Kabupaten Sleman, Yogyakarta. Waktu penelitian adalah semester genap tahun pelajaran 2011/2012 dari bulan Maret 2012 sampai dengan bulan Mei 2012 sebanyak 15 kali pertemuan. Populasi dalam penelitian ini adalah seluruh siswa kelas X SMA Negeri 1 Depok Tahun Pelajaran 2011/2012. Sampel dipilih 3 kelas secara acak dari 6 kelas yang ada.

Terdapat dua variabel yang dilibatkan dalam penelitian ini yaitu variabel bebas dan variabel terikat. Variabel bebas adalah model pembelajaran. Model pembelajaran yang digunakan adalah model pembelajaran kooperatif tipe $S T A D$, pembelajaran kooperatif tipe STAD "plus" dan 
pembelajaran konvensional. Variabel terikat dalam penelitian ini adalah prestasi, minat, dan motivasi belajar matematika. Definisi operasional masing-masing variabel adalah:

1. Pembelajaran kooperatif tipe $S T A D$ adalah pembelajaran dimana guru membagi siswa menjadi kelompok-kelompok yang terdiri dari 4 sampai 5 siswa. Kelompok yang dibentuk adalah kelompok heterogen yang mencerminkan keheterogenan kelas tersebut. Langkah-langkah pembelajarannya adalah sebagai berikut:

a. Presentasi kelas (teach), yaitu: (1) Guru menyajikan informasi awal secara verbal dan atau dengan penggunaan papan tulis tentang materi yang akan dipelajari. Informasi awal yang dimaksud adalah apersepsi materi prasyarat, menyampaikan kegunaan atau penerapan dari materi yang dibahas, menyampaikan tujuan pembelajaran dan memberikan "pengantar singkat" mengenai materi yang dibahas; (2) Siswa bekerja dalam kelompoknya untuk "menemukan" konsep; (3) Guru mendemonstrasikan konsep atau skill yang harus dikuasai siswa, misalnya dengan memberikan contoh soal.

b. Belajar dalam kelompok (team study), yaitu siswa belajar dalam kelompoknya dengan menggunakan LKS yang disediakan guru.

c. Kuis individu (test), yaitu siswa mengerjakan kuis secara individual.

d. Skor perkembangan individu dan penghargaan kelompok (team recognition), yaitu penghitungan skor perkembangan individu berdasarkan nilai kuis terkini dan rata-rata kuis yang sebelumnya yang kemudian dilanjutkan dengan pemberian penghargaan kepada kelompok yang telah mencapai kriteria super team, great team, dan good team.
2. Pembelajaran kooperatif tipe $S T A D$ "plus" adalah sama dengan pembelajaran kooperatif tipe $S T A D$, tetapi pada tahap a) presentasi kelas (teach) bagian (1), yaitu guru menyajikan informasi awal, selain secara verbal, guru juga menggunakan media Power Point yang disisipi gambar atau ilustrasi gambar untuk menginformasikan tentang manfaat atau penerapan trigonometri dalam kehidupan sehari-hari.

3. Pembelajaran konvensional adalah pembelajaran yang biasa dilakukan oleh guru, yaitu dengan langkah-langkah sebagai berikut:

a. Guru menjelaskan materi pelajaran kepada siswa, menyampaikan definisi, teorema, dan lain-lain.

b. Guru memberikan contoh soal yang berkaitan dengan materi yang diajakan.

c. Siswa mengerjakan latihan soal.

d. Guru mengevaluasi jawaban siswa.

4. Prestasi belajar matematika merupakan skor yang diperoleh siswa pada tes prestasi belajar matematika pada materi trigonometri.

5. Minat belajar matematika merupakan skor yang diperoleh siswa dalam memberikan respons berupa perhatian, ketertarikan, dan pilihan siswa terhadap proses pembelajaran matematika, materi matematika, tugas matematika, dan ulangan matematika melalui angket.

6. Motivasi belajar matematika merupakan skor yang diperoleh siswa dalam memberikan respons berupa usaha dan ketekunan siswa ketika belajar mandiri dan ketika proses pembelajaran matematika di kelas, ketika ada tugas matematika, dan ketika ulangan matematika melalui angket.

Instrumen penelitian adalah instrumen tes prestasi, angket minat belajar dan angket motivasi belajar. Seluruh instrumen dinyatakan valid oleh ahli. Analisis faktor instrumen minat dan motivasi berturut-turut 
menghasilkan 7 faktor dan 8 faktor dengan total variance explained adalah $60,001 \%$ dan $62,828 \%$.

Analisis data (statistik inferensial) meliputi: 1) uji t one sample digunakan untuk mendeskripsikan keefektifan pembelajaran kooperatif tipe STAD dan tipe STAD"plus", serta pembelajaran konvensional pada masing-masing variabel terikat; 2) analisis multivariat dengan Helmert Contrast digunakan untuk membandingkan keefektifan pembelajaran kooperatif tipe $S T A D$ dan tipe STAD "plus" serta pembelajaran konvensional secara simultan pada ketiga variabel dependen; 3) uji lanjut dengan Tukey digunakan untuk menganalisis model pembelajaran mana yang lebih efektif antara pembelajaran kooperatif tipe $S T A D$ dan pembelajaran konvensional serta antara pembelajaran kooperatif tipe STAD "plus" dan pembelajaran konvensional ditinjau dari prestasi, minat, motivasi belajar matematika siswa. Setiap analisis dilakukan pada taraf signifikansi $5 \%$.

\section{Hasil dan Pembahasan}

\section{Hasil Penelitian}

Keefektifan pembelajaran diuji dengan uji t one sample, dengan kriteria jika $t_{\text {hitung }}>t_{\text {tabel }}$ maka pembelajaran tersebut dikatakan efektif untuk variabel yang ditentukan. Hasil perhitungan dapat dilihat pada Tabel 1.
Hasil analisis dengan kontras Helmert disajikan pada Tabel 2. Pada GPS 1 diperoleh signifikansi 0,001 (kurang dari 0,05). Hal ini menunjukkan bahwa terdapat perbedaan keefektifan antara rata-rata pembelajaran kooperatif (tipe $S T A D$ dan tipe $S T A D$ "plus") dibandingkan dengan konvensional ditinjau dari prestasi, minat, dan motivasi belajar matematika siswa. Pada GPS 2 diperoleh signifikansi 0,311 (lebih dari 0,05) berarti tidak terdapat perbedaan keefektifan antara pembelajaran kooperatif tipe STAD dibandingkan dengan tipe STAD "plus" ditinjau dari prestasi, minat, dan motivasi belajar matematika siswa.

Hasil uji multivariat kontras Helmert menunjukkan adanya perbedaan keefektifan antara pembelajaran konvensional dengan rata-rata pembelajaran kooperatif tipe $S T A D$ dan STAD "plus ditinjau dari prestasi belajar, minat, dan motivasi belajar siswa. Oleh karena itu, dilakukan uji lanjut untuk menentukan pembelajaran mana yang lebih efektif antara kelas kontrol dengan setiap kelas eksperimen. Uji lanjut menggunakan Tukey (Stevens, 2009: 189). Hasil analisis uji univariat dengan Tukey disajikan pada Tabel 3.

Kriteria keputusan adalah jika nilai signifikansi $<0,05$ berarti ada perbedaan antara dua kelompok yang dibandingkan. Selanjutnya dengan melihat nilai Mean Difference ditentukan kelompok mana yang lebih unggul. Jika Mean Difference positif berarti kelompok pertama lebih unggul

Tabel 1. Hasil Uji t One Sample

\begin{tabular}{|c|c|c|c|c|}
\hline Variabel & Kelas & $t_{\text {hitung }}$ & $t_{\text {tabel }}$ & Keterangan \\
\hline \multirow{3}{*}{ Prestasi } & STAD & 0,053 & \multirow{9}{*}{1,690} & Tidak efektif \\
\hline & STAD "plus" & 1,159 & & Tidak efektif \\
\hline & Konvensional & $-2,245$ & & Tidak efektif \\
\hline \multirow{3}{*}{ Minat } & STAD & 4,154 & & Efektif \\
\hline & STAD "plus" & 4,321 & & Efektif \\
\hline & Konvensional & $-0,594$ & & Tidak efektif \\
\hline \multirow{3}{*}{ Motivasi } & STAD & 5,653 & & Efektif \\
\hline & STAD "plus" & 3,527 & & Efektif \\
\hline & Konvensional & 0,201 & & Tidak efektif \\
\hline
\end{tabular}


daripada kelompok kedua dan sebaliknya jika Mean Difference negatif berarti kelompok kedua lebih unggul daripada kelompok pertama. diberikan dengan bekerjasama dalam kelompok, saling membantu satu sama lain dalam menghadapi masalah dan saling memberikan dorongan untuk mencapai

Tabel 2. Hasil Uji Multivariat Kontras Helmert

\begin{tabular}{|c|c|c|c|c|c|}
\hline Effect & Value & Exact $F$ & Hypothesis df & Error $d f$ & Sig. \\
\hline GPS 1 Wilks' Lambda & 0,85930 & 5,62184 & 3,00 & 103,00 & 0,001 \\
\hline GPS 2 Wilks' Lambda & 0,96607 & 1,20576 & 3,00 & 103,00 & 0,311 \\
\hline
\end{tabular}

Tabel 3. Hasil Uji Univariat dengan Tukey

\begin{tabular}{|c|c|c|c|c|c|}
\hline Variabel & Kelas I & Kelas J & $\begin{array}{c}\text { Mean } \\
\text { Difference } \\
\text { (I-J) }\end{array}$ & Sig. & Keterangan \\
\hline \multirow{2}{*}{ Prestasi } & \multirow{2}{*}{ Konvensional } & STAD & $-5,7222$ & 0,354 & Tidak terdapat perbedaan \\
\hline & & STAD "plus" & $-8,5556$ & 0,102 & Tidak terdapat perbedaan \\
\hline \multirow{2}{*}{ Minat } & \multirow{2}{*}{ Konvensional } & STAD & $-7,7500$ & 0,008 & $\begin{array}{l}\text { Terdapat perbedaan, } \\
\text { Kelas J unggul }\end{array}$ \\
\hline & & STAD "plus" & $-9,7222$ & 0,001 & $\begin{array}{l}\text { Terdapat perbedaan, } \\
\text { Kelas J unggul }\end{array}$ \\
\hline \multirow{2}{*}{ Motivasi } & \multirow{2}{*}{ Konvensional } & STAD & $-9,2778$ & 0,012 & $\begin{array}{l}\text { Terdapat perbedaan, } \\
\text { Kelas J unggul }\end{array}$ \\
\hline & & STAD "plus" & $-8,1111$ & 0,032 & $\begin{array}{l}\text { Terdapat perbedaan, } \\
\text { Kelas J unggul }\end{array}$ \\
\hline
\end{tabular}

\section{Pembahasan}

Hasil uji t one sample menunjukkan bahwa pembelajaran STAD dan STAD "plus" efektif ditinjau dari minat dan motivasi. Hasil analisis multivariat dengan kontras Helmert yang pertama (GPS 1) menunjukkan bahwa terdapat perbedaan keefektifan antara kelas konvensional dengan rata-rata kelas pembelajaran kooperatif tipe $S T A D$ dan STAD "plus" ditinjau dari prestasi, minat, dan motivasi belajar matematika. Hasil analisis univariat dengan Tukey, ditinjau dari minat dan motivasi belajar matematika, pembelajaran kooperatif tipe $S T A D$ dan STAD "plus" sama-sama lebih efektif atau lebih unggul daripada pembelajaran konvensional. Hasil penelitian ini sesuai dengan hipotesis penelitian yang diajukan. Penerapan model pembelajaran kooperatif tipe $S T A D$ dan STAD "plus" memberikan kesempatan kepada siswa untuk mempelajari materi-materi yang keberhasilan yang maksimal. Berdasarkan pengamatan selama pembelajaran berlangsung, pada materi trigonometri, siswa terlihat perhatian, serius, dan tekun dalam mempelajari dan membahas LKS dan aktif berdiskusi. Sebagaimana diungkapkan oleh Elliot, et al., (2000: 349) yang menyatakan bahwa "learning to work cooperatively with other students" dapat membangkitkan minat siswa dan Wina Sanjaya (2011: 29-31) menyatakan bahwa adanya minat dan kerjasama dalam belajar dapat meningkatkan motivasi belajar siswa.

Selanjutnya, Elliot, et al. (2000: 359) menyatakan 'motivation for cooperative learning is associated with the goal structures and potential rewards for group members". Adanya struktur tugas dan penghargaan bagi kelompok dapat memberi motivasi belajar bagi siswa. Adanya kuis pada setiap akhir pembelajaran yang dihitung berdasarkan kemajuan kelompok secara tidak langsung 
memberikan tanggung jawab kepada siswa untuk keberhasilan kelompok masing-masing. Rekognisi atau penghargaan kelompok juga membuat senang dan terpacu untuk belajar, serta menjadi lebih baik dari sebelumnya. Hal ini juga didukung oleh hasil penelitian Slavin (2008: 35) yang menyatakan bahwa di dalam kelas kooperatif siswa berusaha selalu hadir di kelas, dan membantu yang lainnya untuk belajar, dipuji dan didukung oleh teman satu timnya.

Khusus pada kelas STAD "plus", adanya penggunaan media Power Point yang disisipi gambar atau ilustrasi gambar yang berkaitan dengan kegunaan atau manfaat trigonometri dalam kehidupan di tahap "teach", tampak bahwa siswa antusias dan perhatian ketika guru mempresentasikan slide-slide Power Point dan mendengarkan penjelasan yang disampaikan guru berkaitan dengan apa yang ditayangkan. Hal ini tentunya berimplikasi pula pada meningkatnya minat dan motivasi siswa pada kelas STAD "plus" untuk mempelajari trigonometri.

Selanjutnya, uji $t$ one sample menunjukkan bahwa ditinjau dari prestasi belajar matematika siswa, pembelajaran kooperatif tipe $S T A D$ dan pembelajaran kooperatif tipe $S T A D$ "plus", keduanya tidak efektif ditinjau dari prestasi belajar matematika siswa. Hasil analisis univariat dengan Tukey, ditinjau dari prestasi belajar matematika, pembelajaran kooperatif tipe STAD dan STAD "plus" sama-sama tidak lebih efektif daripada pembelajaran konvensional. Hal ini tidak sesuai dengan hipotesis yang diajukan. Padahal salah satu tujuan pembelajaran kooperatif adalah untuk meningkatkan prestasi akademik (Arends, 2000: 315; Lickona, 1991: 187; Johnson, Johnson, \& Holubec 1987: 2). Dalam pembelajaran kooperatif siswa akan belajar bersama dalam kelompok kecil untuk saling mendukung untuk meningkatkan belajar mereka sendiri dan orang lain (Jollife, 2007:
3). Dengan belajar bersama siswa akan dapat saling mengisi kelemahan pemahaman masing-masing, sebagaimana diungkapkan oleh Slavin (1995: 2) bahwa " in cooperative classrooms...fill in gaps in each other understands", karena sering siswa dapat menjelaskan ide-ide sulit kepada temannya dengan menerjemahkannya dari bahasa guru ke bahasa anak yang lebih mudah untuk mereka pahami (Slavin, 1995: 4). Selain itu, dalam pembelajaran kooperatif, adanya kuis dan adanya penghargaan kelompok yang dihitung berdasarkan skor kemajuan individual memberi motivasi belajar siswa. Motivasi memiliki korelasi positif dengan prestasi akademik (Yunus \& Ali, 2009: 99). Hasil penelitian Slavin dan kawan-kawan (Slavin, 1995: 41) menunjukkan bahwa dari 29 penelitian dengan menerapkan STAD, $69 \%$ menunjukkan hasil yang positif terhadap prestasi belajar siswa, $31 \%$ menunjukkan tidak ada perbedaan antara prestasi kelas STAD dibandingkan dengan kelas tradisional, dan tidak satupun penelitian yang menunjukkan hasil negatif.

Dalam pembelajaran kooperatif tipe STAD dan STAD "plus" siswa harus diberi cukup waktu ketika belajar dalam kelompok untuk mereka saling belajar dan mengajar dalam rangka untuk menguasai materi, sebagaimana diungkapkan oleh Killen (2009: 229), yaitu "give the learners sufficient time to work together to understand the ideas you have presented several periods if necessary". Berdasarkan hasil pengamatan selama penelitian, sering siswa tidak diberi cukup waktu ketika belajar di kelompok, karena terbatasnya waktu yang tersedia. Seharusnya, ketika belajar dalam kelompoknya, tidak satu pun dari siswa berhenti belajar sampai mereka benar-benar yakin bahwa teman satu timnya akan mendapat nilai 100. Jadi semuanya harus benar-benar saling belajar dan mengajari sampai semua anggota kelompoknya benarbenar paham. Namun dalam penelitian ini, hal ini tidak dapat terlaksana dengan optimal. 
Apalagi banyak siswa masih bermasalah dalam materi prasyarat seperti merasionalkan pecahan dengan penyebut mengandung tanda akar, operasi aljabar, dan teorema Phytagoras.

Hasil uji multivariat kontras Helmert yang kedua (GPS 2), menunjukkan bahwa tidak ada perbedaan keefektifan antara pembelajaran kooperatif tipe $S T A D$ dan $S T A D$ "plus" ditinjau dari prestasi, minat, dan motivasi belajar. Padahal STAD "plus" memiliki nilai plus dibandingkan dengan $S T A D$, yaitu plus penggunaan media Power Point dengan sisipan gambar atau ilustrasi gambar tentang penerapan atau keterkaitan trigonometri dengan kehidupan sehari-hari. Dalam kelas STAD (tanpa Power Point), pada tahap "teach", selain secara verbal, guru juga menggunakan teknik visual dengan media papan tulis. Dalam kelas STAD, guru menggunakan sketsa gambar (yang digambar di papan tulis) untuk memperjelas informasi verbal yang disampaikan. Hal ini menyebabkan tidak terdapatnya perbedaan keefektifan antara model pembelajaran kooperatif tipe STAD dan STAD "plus" ditinjau dari prestasi, minat, dan motivasi belajar matematika siswa.

Namun, walaupun tidak terdapat perbedaan keefektifan antara model pembelajaran kooperatif tipe $S T A D$ dan STAD "plus", keduanya terbukti efektif mampu meningkatkan minat dan motivasi belajar matematika, khususnya pada materi trigonometri. Karena tidak terdapat perbedaan antara STAD dan STAD "plus" maka kedua model pembelajaran tersebut layak untuk dijadikan pilihan dalam pembelajaran matematika materi trigonometri. Namun menurut pengamatan selama penelitian, dalam pembelajaran kooperatif tipe STAD "plus", pengelolaan kelas lebih mudah. Dengan ditayangkannya Power Point dengan sisipan gambar atau ilustrasi gambar berkaitan dengan materi yang dibahas, perhatian siswa langsung tertuju pada pembelajaran. Berdasarkan uraian di atas, maka dapat dibuat suatu rekomendasi bahwa untuk pembelajaran trigonometri, guru dapat melakukan inovasi pembelajaran dalam rangka untuk meningkatkan prestasi, minat, dan motivasi belajar matematika siswa adalah dengan menerapkan pembelajaran kooperatif tipe STAD "plus".

Dalam pembelajaran konvensional, hasil penelitian ini menunjukkan bahwa pembelajaran konvensional tidak efektif ditinjau dari prestasi, minat, dan motivasi belajar matematika siswa. Beberapa hal yang menyebabkan pembelajaran konvensional tidak efektif adalah: 1) proses pemberian informasi hanya berlangsung satu arah, yaitu dari guru ke siswa sehingga siswa tidak terpacu untuk menemukan sendiri informasi yang terkait dengan materi. Konsep-konsep disampaikan oleh guru, bukan "ditemukan sendiri" oleh siswa, sehingga hal tesebut menyebabkan siswa kurang memahami konsep tersebut dan jadinya mudah lupa; 2) tanggung jawab hanya untuk diri siswa sendiri sehingga kurang ada upaya untuk optimalisasi diri; 3) media yang digunakan hanya buku teks dan papan tulis, sehingga kurang menarik bagi siswa.

\section{Kesimpulan}

Berdasarkan hasil analisis data dan pembahasan, maka dapat disimpulkan beberapa hal sebagai berikut:

1. Pembelajaran kooperatif tipe $S T A D$ dan STAD "plus" efektif ditinjau dari minat dan motivasi belajar matematika tetapi tidak efektif ditinjau dari prestasi belajar matematika, sedangkan pembelajaran konvensional tidak efektif ditinjau dari ketiga variabel dependen.

2. Pembelajaran kooperatif tipe $S T A D$ dan $S T A D$ "plus" lebih efektif daripada pembelajaran konvensional ditinjau dari minat dan motivasi belajar matematika siswa. 
3. Tidak terdapat perbedaan keefektifan antara pembelajaran kooperatif tipe $S T A D$ dan STAD "plus" ditinjau dari prestasi, minat, dan motivasi belajar matematika siswa.

Hasil penelitian menunjukkan bahwa penerapan pembelajaran kooperatif tipe $S T A D$ tanpa dan dengan penggunaan media Power Point di tahap "teach" yang disisipi gambar atau ilustrasi gambar tentang manfaat atau penerapan trigonometri dalam kehidupan (tipe STAD "plus") efektif ditinjau dari minat dan motivasi belajar matematika siswa Oleh karena itu, model pembelajaran kooperatif tipe STAD dan tipe STAD "plus" dapat menjadi alternatif model pembelajaran yang dapat digunakan untuk meningkatkan minat dan motivasi belajar matematika siswa. Disarankan kepada pengajar matematika, dalam pembelajaran kooperatif tipe $S T A D$ dan tipe STAD "plus", siswa harus diberi cukup waktu dalam belajar di kelompoknya, sehingga diharapkan siswa benar-benar saling belajar dan saling mengajari sampai semua anggota kelompoknya benar-benar paham.

\section{Daftar Pustaka}

Arends, R.I, 2000. Learning to teach $\left(5^{\text {th }} e d\right)$. New York: McGraw-Hill

Elliot, S. N., Kratochwill, T. R, Cook, J. L., et.al., 2000. Educational psychology: effective teaching, effective learning. Boston, MA: The McGraw-Hill Companies, Inc.

Johnson, D.W., Johnson, R.T., \& Holubec, E.J., 1987. Learning together and alone. Minneapolis, MN: University of Minnesota.

Jolliffe, W., 2007. Cooperative learning in the classroom: putting it into practice. London: Paul Chapman Publishing.

Killen, R., 2009.Effective teaching strategies: lessons from research and practice $\left(5^{\text {th }}\right.$ ed.). South Melbourne: Cengage Learning.
Kozma, R. B. 1994. A reply: media and methods. Educational Technology Research and Development, Vol. 42, No. 3 (1994), pp. 11-14.

Lickona, T., 1991. Education for character. How our school can teach respect and responsibility. New York: Bantam Books.

McMillan, J. \& Schumacher, S., 2010. Research in education: evidence-based inquiry. Boston, MA: Pearson Education.

Muhibbin Syah., 2010. Psikologi pendidikan: dengan pendekatan baru. Bandung, PT. Remaja Rosdakarya.

Orlich, D. C., Harder, R. J, Callahan, R. C, et al., 2007. Teaching strategies. A guide to effective instruction. Boston, MA: Houghton Mifflin Company.

Ormrod, J. E., 2003. Educational psychology developing learners $\left(4^{\text {th }}\right.$ ed.). Upper Saddle River, NJ: Pearson Education

Schunk, D. H, Pintrich, P. L. \& Meece, J. L., 2010. Motivation in education, theory, research, and application. London: Pearson Education Internasional.

Slavin, R. E.,1995. Cooperative learning. Theory, research, and practice. Boston, MA: Allyn \& Bacon.

2008. Cooperative learning, teori, riset, and praktik. (terjemahan oleh Narulita Yusron) London: Allyn \& Bacon (Buku asli diterbitkan tahun 2005)

Stevens, J. P., 2009. Applied multivariate statistics for the social sciences. New York: Routledge

Wina Sanjaya, 2011. Strategi pembelajaran berorientasi standar proses pendidikan. Jakarta: Kencana Prenada Media Group.

Yunus, A. S. Md \& Ali, W. Z. W., 2009. Motivation in the learning of mathematics. European journal of Social Sciences, Volume 7, Number 4. 